\title{
A new species of Falsocaenia (Coleoptera: Lycidae) from Brazil
}

\author{
Elynton A. do Nascimento' (i) \& Milada Bocakova² (D)
}

\footnotetext{
1. Departamento de Engenharia Ambiental, Universidade Estadual do Centro-Oeste, PR 153, Km 7, Riozinho, Caixa Postal 21, $84500-000$ Irati, PR, Brazi (elynton@yahoo.com)

2. Department of Biology, Faculty of Education, Palacky University, Purkrabska 2, Cz-77140 Olomouc, Czech Republic. (milada.bocakova@upol.cz)
}

Received 5 February 2019

Accepted 4 April 2019

Published 23 May 2019

DOI 10.1590/1678-4766e2019019

ABSTRACT. A new species of Lycidae, Falsocaenia santatereza sp. nov. is described and illustrated. This species is a member of a Müllerian mimicry ring from the Atlantic Forest in Brazil, presenting color pattern also found in other sites of Neotropical region. There are now 15 species from Falsocaenia Pic, 1922, all restricted to Neotropical region. Additionally, a new site of occurrence is registered for Falsocaenia paranana (Pic, 1922).

KEYWORDS. Taxonomy, new species, Neotropical Region, Atlantic Forest, mimicry.

In the course of investigation of mimicry in Lycidae from the Atlantic Forest in Southeastern Brazil, many individuals sharing particular color patterns were recognized (NAscimento, 2009). One of the undescribed species that belongs to these Müllerian rings is a member of Falsocaenia Pic, 1922, a small genus of the tribe Calopterini currently containing 14 described species. The group has been revised recently (BOCAKOVA et al., 2012), and a new species described later (FERREIRA, 2016). NASCIMENTO \& BocaKova (2017) elevated $F$. irregularis var. germaini Pic, 1931 to species rank and extended the distribution of $F$. paranana (Pic, 1922) to Paraguay, a species described originally from Argentina and also found in Brazil (NAScimento, 2013). Hence, all species of Falsocaenia are restricted to Neotropical region with three species recorded from Brazil so far.

Within Calopterini, members of Falsocaenia are similar to those presumably neotenic taxa Lycomorphon Pic, 1922 and Brasilycus Nascimento \& Bocakova, 2010 whose females are unknown (NASCIMENTO \& Bocakova, 2009, 2010). Particularly, species of Falsocaenia and Lycomorphon share large rectangular elytral cells, while the cells of Brasilycus are small and irregular. External morphological differences are scanty, but the elytral costa 3 is fully developed in members of Falsocaenia, while reaches only elytral midlength in those of Lycomorphon. Conversely, male genitalia characters as the presence of parameral sulci are shared by Falsocaenia and Brasilycus. With both sexes fully winged, Falsocaenia species can be distinguished from other Calopterini genera by the following combination of diagnostic characters: antennae serrate, pronotum with median longitudinal carina well-developed, bifurcate, forming a longitudinal groove distally, each elytron with
3 longitudinal costae and residual costa 3 present basally, male genitalia with shortened parameres, slender phallus presenting distal portion oval or circularly enlarged, and female genitalia with rudimentary valvifers (BOCAKOva, 2003; Bocakova et al., 2012).

In this paper we describe and illustrate a new species of Falsocaenia, the fourth registered in Brazil.

\section{MATERIALS AND METHODS}

The specimens were examined under Zeiss SteREO Discovery V8 stereoscopic microscope and were illustrated using digital photographs taken with Axiocam ERc 5s camera. All measurements are in $\mathrm{mm}$. The eye diameter was measured at the widest point, the interocular distances at the narrowest point. Male genitalia were dissected after short boiling in $10 \% \mathrm{KOH}$ solution.

Abbreviations used are DZUP: Coleção Entomológica Pe. J. S. Moure, - Departamento de Zoologia da Universidade Federal do Paraná, Curitiba, Brazil; MZSP: Museu de Zoologia da Universidade de São Paulo, São Paulo, Brazil.

\section{TAXONOMY}

\section{Falsocaenia santatereza sp. nov.}

(Figs 1-4)

urn:lsid:zoobank.org:pub:55C10FF0-4083-4F6F-A748-

$$
\text { E121326E3FE0 }
$$

Type material. Holotype $\curvearrowright$, BRAZIL: "BRASIL, SP, Ribeirão Preto; Mata Sta. Tereza - E.E. Ribeirão Preto; 

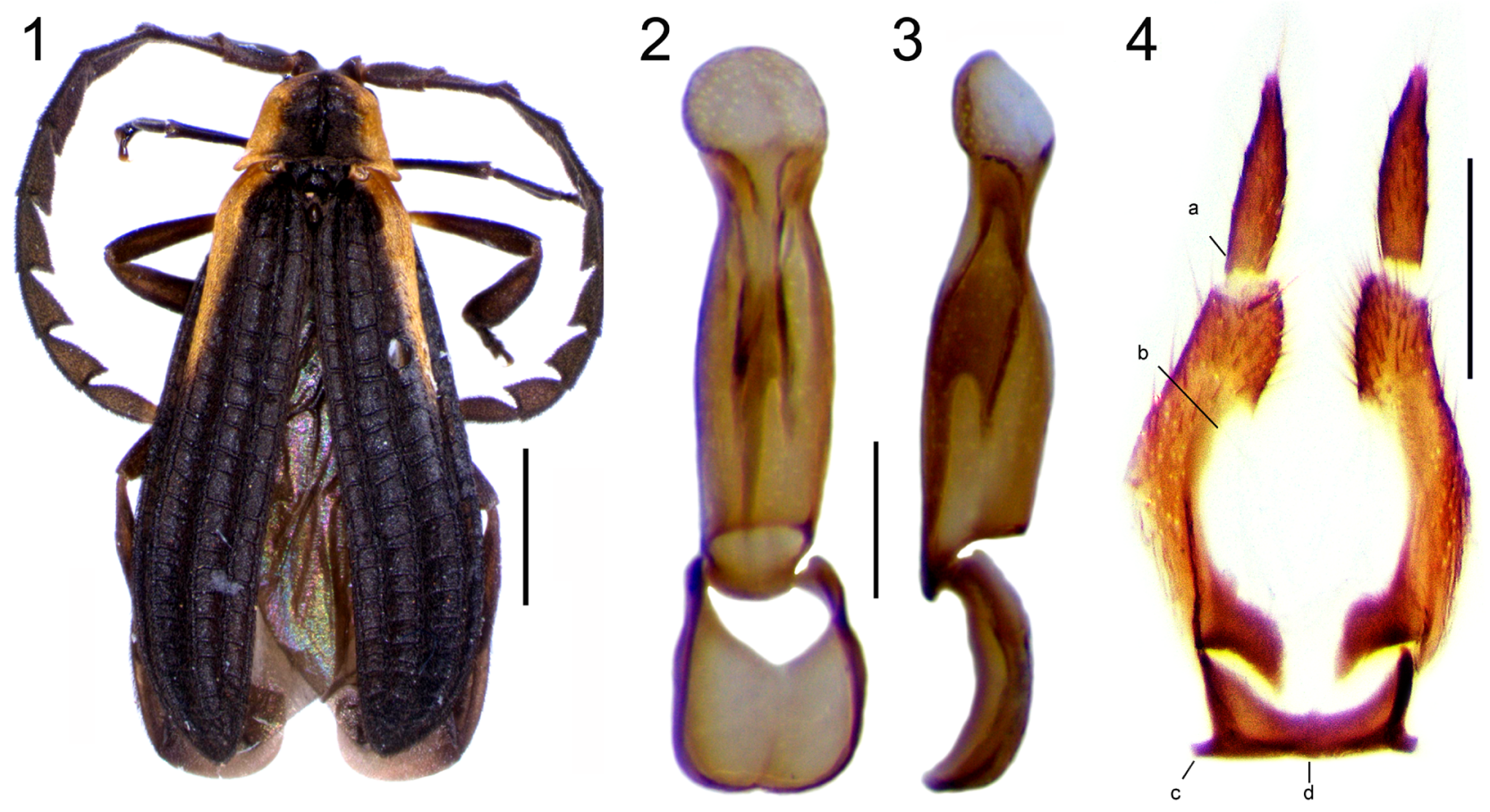

Figs 1-4. Falsocaenia santatereza sp. nov.: 1, habitus, scale=1 mm; male genitalia: 2, ventral; 3, lateral. 4, Female genitalia; a - stylus, $\mathrm{b}-$ median emargination of the coxite, $\mathrm{c}$ - rudimentary valvifers, $\mathrm{d}$ - ventral valviferal bridge. Figs $2-4$, scale $=0.5 \mathrm{~mm}$.

15.ii.2007; 2113’31.1’'S, 4751’5.7’W; Nascimento, EA; Polegatto, CM col." (DZUP). Paratypes: 2 , , BRAZIL: same data, respectively: “17.i.2007”; "15.ii.2007” (DZUP).

Diagnosis. Falsocaenia santatereza sp. nov. is similar in coloration to F. ecuadorensis Bocakova, Baciakova \& Nascimento, 2012 and $F$. veracruzi Ferreira, 2016 and can be differentiated by presenting longer yellow stripes at humeral region. Male genitalia robust in lateral view with basal half straight dorsally in lateral view, with strong ventral constriction after phallus midlength in lateral view. Phallobase larger than phallus + parameres in ventral view. Female genitalia with valvifers forming thin ventral bridge straight posteriorly (Figs 2-4).

Description. Body dark brown to black, pronotum dark brown with lateral sides yellow, elytra dark brown to black with humeral region to $1 / 3$ basal elytra yellow (Fig. 1). Male with maxillary palpomeres 1-2 light brown, palpomeres 3-4 dark brown and labial palpomeres dark brown. In female, maxillary palpomeres 1-2 light brown, palpomere 3 with basal half light brown and apical half dark brown and ultimate palpomere dark brown; first labial palpomere light brown, palpomere 2 with basal half light brown and apical half dark brown, ultimate palpomere dark brown. Legs dark brown, except for whole trochanter and basal $1 / 5$, that present light yellow color. Antennae dark brown, last antennomere with distal $1 / 3-1 / 4$ yellow in male, antennae entirely dark brown in female.

Eyes medium-sized, distance between eyes 1.6-1.7× longer than eye diameter. Mandibles curved, labrum transverse with distal median emargination. Maxillary palpi with palpomere 2 three times longer than 3 in male and in female, palpomere 3 two times longer than 4 in male, and 1.5 time longer than 4 in female. Ultimate palpomere apically pointed. Antennae serrate, with antennomere 4 about $1.1 \times$ longer than antennomere 3 and 5. Prosternum triangular, mesosternum trapezoidal. Pronotum transverse, trapezoidal, widest at base, median longitudinal carina bifurcate, forming longitudinal groove in distal half, medially 1.2-1.3 time wider than long. Scutellum with deep median distal emargination. Elytra slender, $3.2 \times$ longer than wide in humeral portion in male and female, widest in distal third. Each elytron with three longitudinal costae, costa 3 present basally with solely vestiges along the elytra (Fig. 1). Legs compressed, tibiae $1.1 \times$ longer than femur and three times longer than trochanter. Male sternum 8 with shallow median distal emargination. Male terminal sternum elongate, proximally rounded. Spiculum gastrale absent. Male genitalia with terminal circular enlargement of phallus as wider as parameres width medially, phallus 1.2 times longer than parameres length, robust in lateral view with basal half of dorsal portion almost straight in lateral view, ventral portion presenting strong constriction after phallus midlength in lateral view. Phallobase larger than phallus + parameres in ventral view (Figs 2, 3). Female genitalia flattened, valvifers strongly shortened, basally fused forming thin ventral bridge (Fig. 4d) with posterior margin almost straight, coxites long, medially emarginated (Fig. 4b) and approached in distal third, styli as long as half of coxites (Fig. 4). Body length: $5.9 \mathrm{~mm}$ (male) and 6.5-7.1 mm (female), humeral width: $1.6 \mathrm{~mm}$ (male), $1.8 \mathrm{~mm}$ (female). 
Etymology. Species epithet for popular name of type-locality Mata Santa Tereza (Santa Tereza Forest), a Conservation Unit named officially as Estação Ecológica de Ribeirão Preto (Ribeirão Preto Ecologic Station).

Comments. All specimens were collected flying or on leaves of the shrub layer and understory, at a height ranging from $1 \mathrm{~m}$ to $2 \mathrm{~m}$, at 11:30 a.m. to 1:00 p.m., from January to March.

Distribution. Southern Brazil, São Paulo state, municipality of Ribeirão Preto.

\section{Falsocaenia paranana (Pic, 1922)}

Idiopteron (Falsocaenia) parananum Pic, 1922:24.

Falsocaenia paranana (Pic, 1922): Bocakova, 2003: 229.

Specimen examined. BRAZIL, São Paulo: Caraguatatuba (Res. Flor. - 40m.); 22.v-1.vi.1962; Exp. Dep. Zool. (MZSP).

Comments. BocaKova et al. (2012) redescribed Falsocaenia paranana, originally described by PIC (1922) from Argentina (Provincia de Misiones). NAscimento \& BocAKova (2017) extended the species distribution, registering F paranana also to Brazil (Southeastern region, São Paulo state, municipality of Jundiaí) and Paraguay (Kanindeyu Department, municipality of Curuguaty). Here we register a new site of occurrence to this species from Brazil, also in São Paulo state, but in the city of Caraguatatuba, localized at Brazilian coast, $160 \mathrm{~km}$ away from Jundiaí and about $1.000 \mathrm{~km}$ away from Curuguaty and Misiones.

Acknowledgements. EAN is very grateful to Cleber M. Polegatto for help in field work and MB acknowledges a grant CZ.1.07/2.3.00/20.0166 (European Social Fund and Ministry of Education of the Czech Republic).

\section{REFERENCES}

Bocakova, M. 2003. Revision of the tribe Calopterini (Coleoptera, Lycidae). Studies on Neotropical Fauna and Environment 38(3):207-234.

Bocakova, M.; Baciakova, B. \& Nascimento, E. A. 2012. Revision of the genus Falsocaenia (Coleoptera: Lycidae). Zootaxa 3478:282-296.

Ferreira, V. S. 2016. A new species of Falsocaenia Pic, 1922 from Amazonian Rainforest (Coleoptera: Lycidae) with an updated key to the species. Zootaxa 4105:497-499. doi: http://doi.org/10.11646/ zootaxa.4105.5.6

NASCimento, E. A. 2013. The current status of knowledge on Lycidae Laporte, 1836 from Brazil (Insecta: Coleoptera). Check List 9(2):323-328.

Nascimento, E. A. \& Bocakova, M. 2009. A revision of the genus Lycomorphon (Coleoptera: Lycidae). Zootaxa 2132:40-52.

Nascimento, E. A. \& Bocakova, M. 2010. A new genus of net-winged beetles from Neotropical Region (Coleoptera: Lycidae). Annales de la Société Entomologique de France 46(3-4):449-452.

NASCimento, E. A. \& BocaKova, M. 2017. Neolinoptes gen. n., a replacement name for the net-winged beetle genus Linoptes Gorham, 1884 and a new species of Lycomorphon from Guyana (Coleoptera: Lycidae). Zootaxa 4216:395-400. doi: https://doi.org/10.11646/zootaxa.4216.4.7 PIC, M. 1922. Contribution a l'étude des Lycides. L'Echange 407-410:1328 hors texte. 